\title{
Trust Development and Transfer from Electronic Commerce to Social Commerce: An Empirical Investigation
}

\author{
Lei Chen ${ }^{1,2}$, Ruimei Wang ${ }^{*}$ \\ ${ }^{1}$ College of Economics and Management, China Agricultural University, Beijing, China \\ ${ }^{2}$ School of Information, Beijing WUZI University, Beijing, China \\ Email: "susychenlei@163.com
}

Received 4 April 2016; accepted 10 May 2016; published 13 May 2016

Copyright (C) 2016 by authors and Scientific Research Publishing Inc.

This work is licensed under the Creative Commons Attribution International License (CC BY). http://creativecommons.org/licenses/by/4.0/

(c) (i) Open Access

\begin{abstract}
The development of social networking sites (SNSs) and Web 2.0 technology have given rise to a new electronic commerce paradigm called social commerce. Social commerce is a subset of electronic commerce and uses SNSs for social interactions and user contributions to facilitate the online buying and selling of products and services. Recent years have witnessed the rapid growth of social commerce in China, but users are not willing to share their online shopping information and the intention to use social commerce is lower than traditional electronic commerce. So improving Consumers' trust and use intention has become a crucial factor in the success of social commerce. Since social commerce users mostly are e-commerce users, this paper discusses whether trust on e-commerce can transfer to social commerce, and what are the factors influencing trust and trust performance of social commerce. The results of an empirical analysis based on a sample of 449 users with online shopping experience indicate that consumers' trust in e-commerce has a significant positive impact on trust in social commerce and relative advantage; perceived relative advantage and result demonstrability positively affect customers' trust in social commerce and trust in social commerce positively affects their intention to use; while perceived risk negatively affects a customer's intention to use.
\end{abstract}

\section{Keywords}

Social Commerce, Electronic Commerce, Trust, Trust Transfer, Use Intention, Relative Advantage

\section{Introduction}

With the rapid development of electronic commerce in China, the competition in the traditional e-commerce is ${ }^{*}$ Corresponding author. 
becoming increasingly fierce, and the profit space is limited. In order to attract more consumers to shop online, many businesses began to develop social marketing in e-commerce, which is a new mode of e-commerce named social commerce. According to the survey data released by China Internet Network Information Center (CNNIC), although social commerce is a promising form of electronic commerce, the consumers' willingness to use is not high, probably because they don't trust the way of online shopping combined with social participation and discussion. The consumers may be disgusted with too much advertising and sales promotions, worrying about too much disclosure of personal privacy and poor transaction security, and don't trust the reliability and authenticity of other people's online evaluation. So trust is still a main influencing factor for consumers to use a social commerce website.

As social commerce is the combination of e-commerce and social network, one form of social commerce is adding social functions in the e-commerce site to promote online shopping. Many social commerce websites such as Taobao are trying to develop social commerce in China. Social commerce users usually have good skills and experience of e-commerce, and they usually have trust and loyalty for e-commerce websites. This paper discusses whether trust on e-commerce can transfer to social commerce, and what are the factors influencing the trust and trust performance of social commerce.

\section{Previous Research}

\subsection{Social Commerce}

The development of social networking sites (SNSs) and Web 2.0 technology have given rise to a new electronic commerce paradigm called social commerce. Social commerce has been a hot topic for researchers in recent years. Social commerce is a subset of electronic commerce and uses SNSs for social interactions and user contributions to facilitate the online buying and selling of various products and services (Kim and Park, 2013; Hajli, 2014) [1] [2]. Social commerce provides a new business online and offline integration environment (Wang and Zhang, 2012) [3] and consumers make purchase decision by means of obtaining and comparing prices through interpersonal interaction, availability, configuration information (Liang and Turban, 2011) [4].

\subsection{Trust and Trust Transfer}

Compared with e-commerce, social commerce is a new business model which is full of uncertainty and risk. Nowadays in China, consumers' intention to use of social commerce is not high, trust is always a very important problem deserving further research to promote the intention of use. Many researchers have studied a lot about trust in social commerce. Sanghyn Kim (2013) claimed that the characteristics of social commerce including reputation, size, information quality, transaction safety, communication and word-of-mouth referrals have a significant impact on consumer trust [1]. Nick Hajli's (2015) study showed that social commerce constructs including ratings and reviews, recommendations and referrals, forums and communities will increase the level of trust and intention to buy [2]. Mahmood (2013) studied the impact of recommendation, community, rating and interactivity during each stage of decision making for user transactions and built up a social commerce adoption model [5]. Harris and Dennis (2013) claimed that recommendations from friends help to change using habits of online shopping and real life friends have higher impact on building consumer trust [6].

Most literatures study the problem of social commerce trust from the perspective of social characteristic, but less research is carried out from the relationship between e-commerce and social commerce. Since there are natural link between e-commerce and social commerce, this paper is going to find the factors influencing consumers' trust transfer from e-commerce to social commerce.

\section{Research Model and Hypotheses}

A social commerce trust model will be developed in this research in order to explain the influence of electronic commerce on social commerce. Specifically, this research investigates some positive factors and negative factors that may affect consumers' trust and intension of use. These are included in the model as shown in Figure 1 .

\subsection{Innovation Diffusion Theory}

The innovation diffusion theory proposed by Rogers (1962) defines innovation diffusion as a social process, 


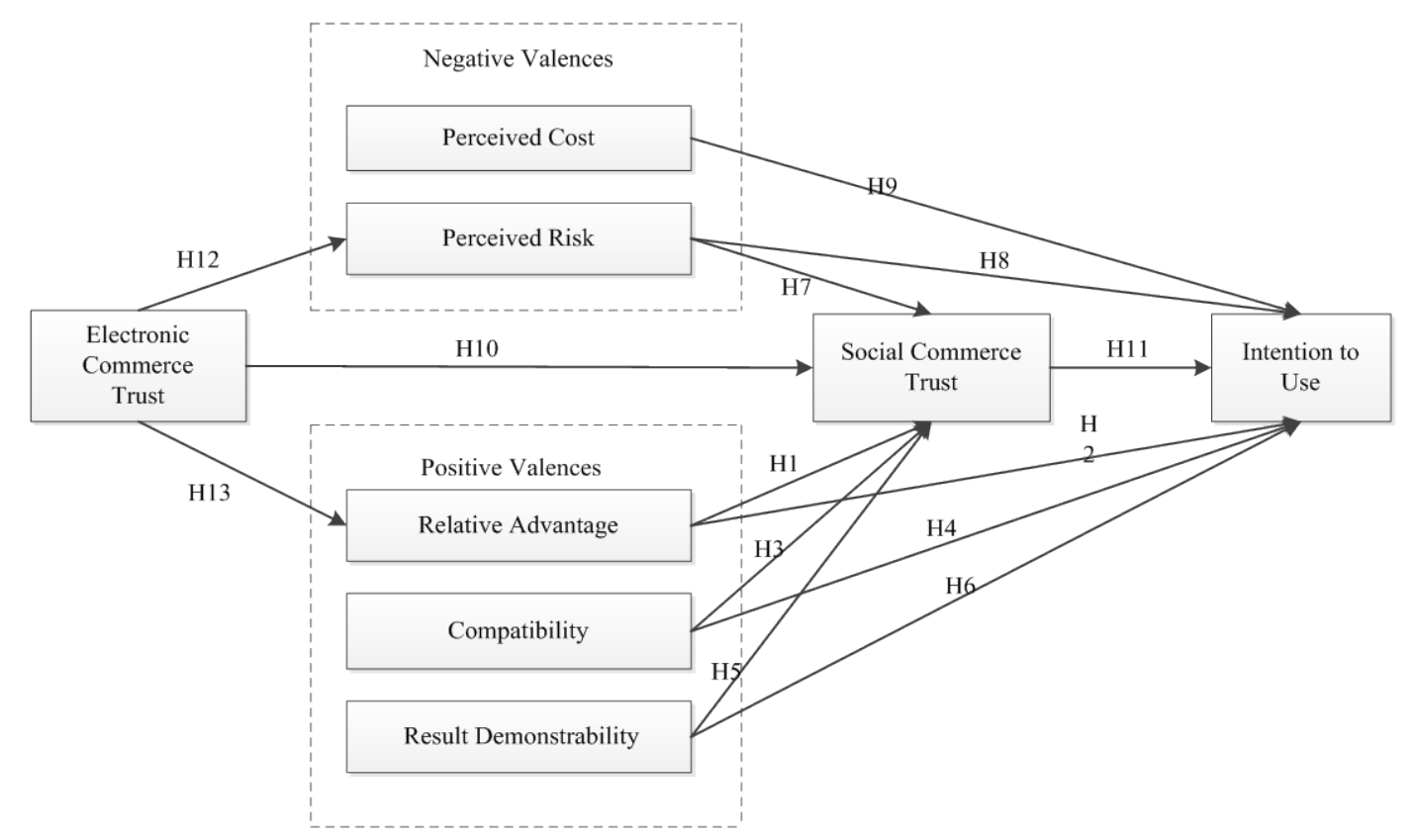

Figure 1. Research model.

during which innovation spread through social systems and organizations over time. Innovation diffusion theory explains the spread of rising technologies from the macro level. Rogers puts forward five major factors affecting diffusion of innovation; they are relative advantage, compatibility, complexity, observability and trialability [7]. Then Moore and Benbasat (1991) extend the five factors to eight factors based on the background of information system and information technology adoption. These include relative advantage, complexity, image, visibility, compatibility, result demonstrability, trialability and voluntary [8]. Previous research of innovation diffusion theory applied in the field of information system show that relative advantage, compatibility and complexity are the most important factors influencing innovation adoption.

In the research background of social commerce, as consumers are skilled with shopping on an e-commerce website, when the online community is added into the website, what are the factors that will lead to consumers' trust and intention of use? Three factors are chosen from the innovation diffusion theory to apply in this research. They are relative advantage, compatibility and result demonstrability. Relative advantage means whether the new business model has more advantages for consumers, for example more conducive to online shopping or more convenient to communicate with friends. Compatibility means whether social commerce and e-commerce are compatible in aspects such as the user's browsing habits, functions, interfaces, security etc. Result demonstrability means social commerce provides a platform that can help users to obtain other people's shopping information and recommendation.

\subsection{Valence Theory}

Valence theory is a kind of consumer decision theory based on rational cognition, and it studies consumer behavior from both positive and negative attributes. The theory considers perceived risk and perceived benefit to be the two fundamental aspects of consumer decision-making. Previous studies show that valence theory is effective for electronic commerce environment. Kim and Ferrin (2009) applied valence theory into the research on the influencing factors of consumer trust and satisfaction in electronic commerce [9]. Yaobin Lu and Shuiqing Yang (2011) developed a trust-based customer decision-making model of the non-independent, third-party mobile payment services context based on a valence framework [10].

We introduce positive valence and negative valence here to explain the influencing factors of consumer trust and intention of use when transferring from electronic commerce to social commerce.

1) Positive valence

Positive valence is the factor that can promote consumer trust and willingness to use in the model. The tradi- 
tional valence theory only tests the impact of perceived benefit. Considering the innovation and new characteristics of social commerce, three constructs of innovation diffusion theory are proposed to be expected to have positive influence on consumers' trust and trust performance. They are relative advantage, compatibility and result demonstrability. We therefore hypothesized:

H1. Relative advantage positively affects a customer's trust to social commerce.

H2. Relative advantage positively affects a customer's intention to use.

H3. Compatibility positively affects a customer's trust to social commerce.

H4. Compatibility positively affects a customer's intention to use.

H5. Result demonstrability positively affects a customer's trust to social commerce.

H6. Result demonstrability positively affects a customer's intention to use.

2) Negative valence

When transferring from e-commerce to social commerce, customers not only perceive positive impact but also bear some risks. Traditional valence theory only tests the impact of perceived risk. We expand the negative valence to perceived risk and perceived cost. In social commerce, when shopping with their friends online, consumers usually share the products information and evaluation with each other, which may lead to the leakage of personal privacy. The Perceived risk may lead to the result that consumers don't trust and are not willing to use social commerce. We thus hypothesized:

H7. Perceived risk negatively affects a customer's trust to social commerce.

H8. Perceived risk negatively affects a customer's intention to use.

The consumers who used to shopping online relying on the business provided product information and personal experience, now will spend much more time and energy maintaining the relationship with friends, reading other people's comments, and looking for satisfied products. The time, money and energy spent during the process may increase cost of shopping and consumers' perceived cost. Therefore we have the following hypotheses:

H9. Perceived cost negatively affects a customer's intention to use.

\subsection{Trust and Trust Transfer Theory}

McKnight (2003) claimed that trust transfer is one of the important mechanisms of trust establishment [11]. K.J. Stewart (2003)'s research show that: people's trust can transfer from source to target when there are relatedness between source and target [12]. The relatedness includes similarity, proximity and common fate. The relatedness between electronic commerce and social commerce covers all the three impacts. Since e-commerce and social commerce have the same purpose of promoting the purchase of goods and services, they are similar, proximate and have the common fate.

As an important business form in China, research findings on e-commerce trust and use intention is very rich and fruitful and consumers have built up high level of trust for e-commerce. If the social network service (SNS) is added in an e-commerce website, consumers' trust in e-commerce will transfer to social commerce. Thus we propose:

H10. E-commerce trust positively affects a customers' trust to social commerce.

H11. Social commerce trust positively affects a customer's intention to use.

Studies on e-commerce trust show that trust can reduce the perceived risk and improve the perception of advantage. Therefore we propose:

H12: E-commerce trust negatively affects customers' perceived risk.

H13: E-commerce trust positively affects customers’ perceived advantage.

\section{Methodology}

\subsection{Instrument}

The research model includes eight constructs, and each construct is measured with 3 - 4 items which are selected from the relevant research literature. Some of items are modified to fit the context of social commerce. A questionnaire including demographics of samples and multi-items of constructs used 7-point Likert scales to measure the degree of agreement. The questionnaire was firstly pre-tested by an expert interview, and then was further revised and improved according to the experts' opinion. After the questionnaire was revised, 20 users were invited to carry out a pilot test, and some items were revised again. The final items are listed in Table 1. 
Table 1. Scales and items.

\begin{tabular}{|c|c|c|}
\hline Constructs & Questionnaire & Source \\
\hline \multicolumn{3}{|c|}{ There may be a risk of disclosing personal information on a social commerce site } \\
\hline $\begin{array}{l}\text { Perceived } \\
\text { risk }\end{array}$ & $\begin{array}{l}\text { There may be a risk of sharing personal shopping information on a social commerce site } \\
\text { There are risks for believing in web reviews and recommendations of a social commerce website. }\end{array}$ & \multirow{2}{*}{$\begin{array}{l}\text { Shwadhin } \\
\text { Sharma, } \\
\text { Robert E. } \\
\text { Crossler } \\
\text { (2014) }\end{array}$} \\
\hline \multirow[t]{2}{*}{$\begin{array}{l}\text { Perceived } \\
\text { cost }\end{array}$} & $\begin{array}{l}\text { I may have to spend more time buying products by using social commerce. } \\
\text { I may have to spend more energy buying products by using social commerce. }\end{array}$ & \\
\hline & I may have to spend more money buying products by using social commerce. & \multirow[b]{2}{*}{$\begin{array}{l}\text { Sanghyun Kim, } \\
\text { Hyunsun Park } \\
\text { (2013) }\end{array}$} \\
\hline $\begin{array}{l}\text { Social } \\
\text { commerce trust }\end{array}$ & $\begin{array}{l}\text { The social commerce website seems to be worthy of trust. } \\
\text { The social commerce website understands my interests and demand. } \\
\text { The information provided by the social commerce website is worthy of trust. }\end{array}$ & \\
\hline \multirow{3}{*}{$\begin{array}{c}\text { Electronic } \\
\text { commerce trust }\end{array}$} & Electronic commerce is worthy of trust. & \multirow{3}{*}{$\begin{array}{l}\text { McKnight } \\
\text { (2002) }\end{array}$} \\
\hline & Electronic commerce is reliable. & \\
\hline & I often go shopping online. & \\
\hline \multirow{3}{*}{$\begin{array}{l}\text { Relative } \\
\text { advantage }\end{array}$} & Social commerce has more advantages, which helps to shop online. & \multirow{9}{*}{$\begin{array}{l}\text { Yao Bin Lu, } \\
\text { Shuiqing Yang, } \\
\text { Patrick Y. K. } \\
\text { Dhau (2011) }\end{array}$} \\
\hline & Social commerce has more advantages, which makes shopping moreefficient & \\
\hline & Social commerce has more advantages, which helps to communicate with friends & \\
\hline \multirow{3}{*}{ Compatibility } & The function of social commerce and electronic commerce is compatible. & \\
\hline & Social commerce and e-commerce have the similar form of shopping. & \\
\hline & I am accustomed to using social commerce shopping & \\
\hline \multirow{3}{*}{$\begin{array}{c}\text { Result } \\
\text { demonstrability }\end{array}$} & $\begin{array}{l}\text { After joining the social community of a web store, my friends' } \\
\text { shopping information is conducive to my shopping }\end{array}$ & \\
\hline & $\begin{array}{l}\text { After joining the social community of a web store, my friends' } \\
\text { comments on products is conducive to my shopping }\end{array}$ & \\
\hline & $\begin{array}{l}\text { After joining the social community of a web store, my friends' } \\
\text { recommendation on products is conducive to my shopping }\end{array}$ & \\
\hline \multirow[t]{2}{*}{$\begin{array}{l}\text { Intention } \\
\text { of use }\end{array}$} & $\begin{array}{l}\text { If a product is recommended by my social network friends, I would like to buy it online. } \\
\text { During online shopping, I would like to accept recommendation and } \\
\text { evaluation of products from my social network friends }\end{array}$ & \multirow[t]{2}{*}{$\begin{array}{l}\text { Celeste } \\
\text { See-Pui } \\
\text { Ng (2013) }\end{array}$} \\
\hline & I would like to share my shopping experience and information to my social network friends & \\
\hline
\end{tabular}

\subsection{Sample Collection}

Social commerce develops from electronic commerce, and is closely related to electronic commerce. In China, the number of people who shop online has reached to four hundred million by December 2015. Electronic commerce has become an important shopping way in people's daily life. With the popularity of the Internet and smart mobile phones, the future development trend is the socialization of electronic commerce. So the survey is aimed at people with the experience of online shopping, to study whether the consumers who have built trust in electronic commerce would also trust social commerce.

Sample data are collected through an online survey, 478 questionnaires were answered by people from different stratums including different education background, level of income, gender, age and other demographics variables. After deleting the responses that give the same answers for all the questions and who have no online shopping experience, we obtain totally 449 questionnaires. The total valid respondents included 218 males and 231 females. $90.4 \%$ response range was from 18 to 50 years old, with $37.8 \%$ of 18 to 30 years and $33.1 \%$ of 30 to 40 years old. 


\subsection{Statistical Analysis}

Except for the descriptive statistical index, data collected from the questionnaires includes all of the model observation variables which are functions of latent variables and observation errors. In this paper, statistical analysis includes exploratory factor analysis and confirmatory factor analysis for all observed variables using SPSS. After deleting unsuitable items, all the factors correspond to the model constructs. Structural function model (SEM) is used to measure causal relationship between latent variables and then build path, thereby the model assumption is verified.

\section{Data analysis and Results}

\subsection{Validity Analysis}

We firstly apply exploratory factor analysis to test the measurement model using Varimax Rotation method. The Kaiser-Meyer-Olkin (KMO) value of sample data is 0.902 and Bartlett's Test of Sphericity is significant at the level of 0.0001, which indicate that the data are suitable for principal component analysis. As shown in Table 2, eight factors are extracted after confirmatory factor analysis and they explain $79.344 \%$ of the variance. In order to guarantee good validity, we need to revise some indicators. The third item of compatibility and the third item of trust in electronic commerce are rejected. As a result, all the indicators loaded on the expected factors are higher than 0.7 , while the indicators loaded on other factors are lower than 0.406, which means good convergent validity and discriminant validity.

Table 2. Factor loadings and cross-loading of the measruement model.

\begin{tabular}{|c|c|c|c|c|c|c|c|c|}
\hline & \multicolumn{8}{|c|}{ Factors } \\
\hline & 1 & 2 & 3 & 4 & 5 & 6 & 7 & 8 \\
\hline RED3 & 0.806 & 0.180 & 0.068 & 0.244 & 0.081 & 0.138 & 0.177 & 0.147 \\
\hline RED2 & 0.800 & 0.253 & 0.042 & 0.274 & 0.116 & 0.179 & 0.054 & 0.136 \\
\hline RED1 & 0.709 & 0.167 & 0.037 & 0.282 & 0.120 & 0.216 & 0.170 & 0.207 \\
\hline REA2 & 0.161 & 0.833 & 0.012 & 0.165 & 0.010 & 0.214 & 0.210 & 0.201 \\
\hline REA1 & 0.227 & 0.802 & 0.076 & 0.184 & 0.102 & 0.196 & 0.224 & 0.101 \\
\hline REA3 & 0.372 & 0.637 & -0.051 & 0.177 & 0.072 & 0.200 & 0.088 & 0.406 \\
\hline PEC1 & 0.072 & -0.034 & 0.877 & -0.008 & 0.214 & -0.015 & 0.062 & 0.125 \\
\hline PEC2 & -0.024 & -0.069 & 0.867 & 0.052 & 0.215 & -0.074 & 0.071 & 0.182 \\
\hline PEC3 & 0.062 & 0.165 & 0.787 & -0.003 & 0.186 & 0.160 & -0.044 & -0.173 \\
\hline IU2 & 0.231 & 0.153 & 0.011 & 0.753 & 0.157 & 0.131 & 0.222 & 0.123 \\
\hline IU1 & 0.244 & 0.110 & 0.057 & 0.737 & 0.059 & 0.209 & 0.186 & 0.165 \\
\hline IU3 & 0.269 & 0.195 & -0.020 & 0.736 & 0.037 & 0.257 & 0.003 & 0.100 \\
\hline PER2 & 0.096 & 0.045 & 0.185 & 0.021 & 0.863 & 0.109 & 0.026 & -0.036 \\
\hline PER1 & 0.111 & 0.010 & 0.123 & 0.113 & 0.854 & -0.024 & -0.063 & 0.125 \\
\hline PER3 & 0.027 & 0.087 & 0.352 & 0.077 & 0.770 & 0.009 & -0.014 & 0.071 \\
\hline TRU_SC2 & 0.206 & 0.239 & -0.020 & 0.236 & 0.024 & 0.737 & 0.284 & 0.100 \\
\hline TRU_SC3 & 0.181 & 0.222 & 0.081 & 0.253 & 0.020 & 0.706 & 0.367 & 0.116 \\
\hline TRU_SC1 & 0.222 & 0.184 & 0.026 & 0.255 & 0.094 & 0.673 & 0.172 & 0.298 \\
\hline TRU_EC2 & 0.160 & 0.250 & 0.027 & 0.175 & -0.040 & 0.242 & 0.825 & 0.102 \\
\hline TRU_EC1 & 0.148 & 0.172 & 0.061 & 0.161 & -0.038 & 0.311 & 0.810 & 0.099 \\
\hline COM2 & 0.240 & 0.216 & 0.148 & 0.176 & 0.077 & 0.259 & 0.084 & 0.730 \\
\hline COM1 & 0.252 & 0.367 & 0.050 & 0.245 & 0.122 & 0.146 & 0.175 & 0.668 \\
\hline Eigen-value & 8.426 & 3.224 & 1.537 & 1.153 & 1.056 & 0.763 & 0.683 & 0.612 \\
\hline Variance \% & 38.302 & 14.653 & 6.987 & 5.240 & 4.802 & 3.470 & 3.107 & 2.783 \\
\hline Cumulative & 38.302 & 52.955 & 59.943 & 65.182 & 69.984 & 73.454 & 76.561 & 79.344 \\
\hline
\end{tabular}




\subsection{Reliability Analysis}

We then conduct a confirmatory factor analysis to further examine the model. The reliability of the measurement model is usually measured by values of Cronbach's Alpha, Composite Reliability (CR) and Average Variance Extracted (AVE). As shown in Table 3, all of the factors' Cronbach's Alpha values are greater than 0.7, the composite reliability is greater than 0.6 and the AVE value exceeds 0.5 , which means good consistency and convergent reliability of the model.

\subsection{Hypothesis Testing}

The research model and the hypotheses are tested using AMOS 17.0, the maximum likelihood estimation method is used to compute path coefficient and fit the model. The fitting index include: $\mathrm{x} 2 / \mathrm{df}=1.373$, GFI $=0.922$, AGFI $=0.894$, CFI $=0.981$, NFI $=0.935$, RMSEA $=0.062$. All of them are within the scope of the proposed value, which means the fitting degree of the model is good. The path coefficients and hypothesis results are shown in Table 4.

The test result certified the hypothesis that consumers' trust in e-commerce has a significant positive impact on trust in social commerce and relative advantage; perceived relative advantage and result demonstrability positively affects customers' trust in social commerce and trust in social commerce positively affects their intention to use; and perceived risk negatively affects a customer's intention to use.

Table 3. Reliability and validity test.

\begin{tabular}{|c|c|c|c|c|c|}
\hline Factors & Items & Factor loadings & Cronbach’s Alpha & Composite reliability & AVE \\
\hline \multirow{3}{*}{ Perceived risk } & PER1 & 0.774 & \multirow{3}{*}{0.837} & \multirow{3}{*}{0.8357} & \multirow{3}{*}{0.629} \\
\hline & PER2 & 0.799 & & & \\
\hline & PER3 & 0.806 & & & \\
\hline \multirow{3}{*}{ Perceived cost } & PEC1 & 0.895 & \multirow{3}{*}{0.844} & \multirow{3}{*}{0.8525} & \multirow{3}{*}{0.6634} \\
\hline & PEC2 & 0.888 & & & \\
\hline & PEC3 & 0.633 & & & \\
\hline \multirow{3}{*}{$\begin{array}{l}\text { Social commerce } \\
\text { trust }\end{array}$} & TRU_SC1 & 0.736 & \multirow{3}{*}{0.839} & \multirow{3}{*}{0.8421} & \multirow{3}{*}{0.6408} \\
\hline & TRU_SC2 & 0.807 & & & \\
\hline & TRU_SC3 & 0.854 & & & \\
\hline \multirow{2}{*}{$\begin{array}{l}\text { Electronic commerce } \\
\text { trust }\end{array}$} & TRU_EC1 & 0.869 & \multirow{2}{*}{0.856} & \multirow{2}{*}{0.856} & \multirow{2}{*}{0.7482} \\
\hline & TRU_EC2 & 0.861 & & & \\
\hline \multirow{3}{*}{ Relative advantage } & REA1 & 0.859 & \multirow{3}{*}{0.885} & \multirow{3}{*}{0.8878} & \multirow{3}{*}{0.7255} \\
\hline & REA2 & 0.89 & & & \\
\hline & REA3 & 0.804 & & & \\
\hline \multirow[b]{2}{*}{ Compatibility } & COM1 & 0.771 & \multirow[b]{2}{*}{0.743} & \multirow[b]{2}{*}{0.7275} & \multirow[b]{2}{*}{0.5718} \\
\hline & COM2 & 0.741 & & & \\
\hline \multirow{3}{*}{ Result demonstrability } & RED1 & 0.784 & \multirow{3}{*}{0.873} & \multirow{3}{*}{0.8684} & \multirow{3}{*}{0.6877} \\
\hline & RED2 & 0.853 & & & \\
\hline & RED3 & 0.849 & & & \\
\hline \multirow{3}{*}{ Intention of use } & IU1 & 0.759 & \multirow{3}{*}{0.8} & \multirow{3}{*}{0.7972} & \multirow{3}{*}{0.5672} \\
\hline & IU2 & 0.768 & & & \\
\hline & IU3 & 0.732 & & & \\
\hline
\end{tabular}


Table 4. Hypothesis results.

\begin{tabular}{|c|c|c|c|c|c|}
\hline Hypotheses & Estimate & S.E. & C.R. & $\mathrm{P}(<0.05)$ & Result \\
\hline H12: Perceived risk <--- Electronic commerce trust & 0.027 & 0.045 & 0.603 & 0.547 & Reject \\
\hline H13: Relative advantage <--- Electronic commerce trust & 0.494 & 0.042 & 11.632 & *** & Accept \\
\hline H10: Social commerce trust <--- Electronic commerce trust & 0.363 & 0.042 & 8.704 & $* * *$ & Accept \\
\hline H7: Social commerce trust <--- Perceived risk & 0.019 & 0.033 & 0.555 & 0.579 & Reject \\
\hline H1: Social commerce trust <--- Relative advantage & 0.33 & 0.045 & 7.286 & *** & Accept \\
\hline H3: Social commerce trust <--- Compatibility & 0.07 & 0.078 & 0.892 & 0.373 & Reject \\
\hline H5: Social commerce trust <--- Result demonstrability & 0.134 & 0.067 & 1.993 & 0.046 & Accept \\
\hline H11: Intention of Use <--- Social commerce trust & 0.372 & 0.069 & 5.384 & $* * *$ & Accept \\
\hline H9: Intention of use <--- Perceived cost & -0.058 & 0.035 & -1.632 & 0.103 & Reject \\
\hline H8: Intention of use <--- Perceived risk & 0.098 & 0.044 & 2.238 & 0.025 & Accept \\
\hline H2: Intention of use <--- Relative advantage & 0.184 & 0.055 & 3.35 & *** & Accept \\
\hline H4: Intention of use <--- Compatibility & -0.056 & 0.085 & -0.657 & 0.511 & Reject \\
\hline H6: Intention of use <--- Result demonstrability & 0.383 & 0.076 & 5.057 & *** & Accept \\
\hline
\end{tabular}

\section{Conclusion and Discussion}

The consumers' trust is very important for online trading in the virtual world which is full of risk and uncertainty. With the rapid development of electronic commerce, most consumers have built trust in online shopping, but they are still lack of trust in social commerce. The theme of this paper is to find the factors that will contribute to consumers' trust transfer from electronic commerce to social commerce.

Adding web community functions in an electronic commerce website is a kind of innovation for e-commerce. Web communities provide a platform for consumers to share products information and discuss with friends, which helps them to increase the efficiency and effect of online shopping. The result of the empirical research shows when using the new function, customers' perceived advantage and result demonstrability can significantly promote consumer trust in social commerce, and then improve the use intention. But consumers will also face the risk of personal privacy disclosure, which will negatively affect consumer trust and willingness to use.

Socialization is the trend of the future development of electronic commerce, so the e-commerce sites and business should be aware of the opportunities and challenges brought about by the socialization of electronic commerce. Specific policy recommendations include building a virtual community in an e-commerce site and taking steps to attract more consumers to participate in information sharing and discussion on the products which can effectively improve consumers' potential purchasing power and increase business revenue.

\section{Acknowledgements}

This paper was aid financially by Beijing Key Laboratory (NO:BZ0211) and Beijing Intelligent Logistics System Collaborative Innovation Center.

\section{References}

[1] Kim, S. and Park, H. (2013) Effects of Various Characteristics of Social Commerce (S-Commerce) on Consumers' Trust and Trust Performance. International Journal of Information Management, 33, 318-332. http://dx.doi.org/10.1016/j.ijinfomgt.2012.11.006

[2] Hajli, M.N. (2014) A Study of the Impact of Social Media on Consumers. International Journal of Market Research, 56, 387-404. http://dx.doi.org/10.2501/IJMR-2014-025

[3] Wang, C. and Zhang, P. (2012) The Evolution of Social Commerce: The People, Management, Technology, and Information Dimensions. Communications of the Association for Information Systems, 31, 105-127. 
[4] Liang, T. and Turban, E. (2011) Introduction to the Special Issue Social Commerce: A Research Framework for Social Commerce. International Journal of Electronic Commerce, 16, 5-14. http://dx.doi.org/10.2753/JEC1086-4415160201

[5] Hajli, M. (2013) A Research Framework for Social Commerce Adoption. Information Management \& Computer Security, 21, 144-154. http://dx.doi.org/10.1108/imcs-04-2012-0024

[6] Harris, L. and Dannis, C. (2011) Engaging Customers on Facebook-Challenges for E-Retailers. Consumer Behavior, 10, 338-346. http://dx.doi.org/10.1002/cb.375

[7] Rogers, E.M. (1995) Diffusion of Innovations. Free Press, New York.

[8] Moore, G.C. and Benbasat, I. (1991) Development of an Instrument to Measure the Perceptions of Adopting an Information Technology Innovation. Information Systems Research, 2, 192-222. http://dx.doi.org/10.1287/isre.2.3.192

[9] Kim, D.J., Ferrin, D.J. and Rao, H.R. (2009) Trust and Satisfaction, Two Stepping Stones for Successful E-Commerce Relationships: A Lon-Gitudinal Exploration. Information Systems Research, 20, 237-257. http://dx.doi.org/10.1287/isre.1080.0188

[10] Lu, Y.B., Yang, S.Q., Chau, P.Y.K., et al. (2011) Dynamics between the Trust Transfer Process and Intention to Use Mobile Payment Services: A Cross-Environment Perspective. Information \& Management, 48, 393-403. http://dx.doi.org/10.1016/j.im.2011.09.006

[11] McKnight, D.H., Choudhury, V. and Kacmar, C. (2003) Developing and Validating Trust Measures for E-Commerce: An Integrative Typology. Information Systems Research, 13, 334-359. http://dx.doi.org/10.1287/isre.13.3.334.81

[12] Stewart, K.J. (2003) Trust Transfer on the World Wide Web. Organization Science, 4, 5-17. http://dx.doi.org/10.1287/orsc.14.1.5.12810 